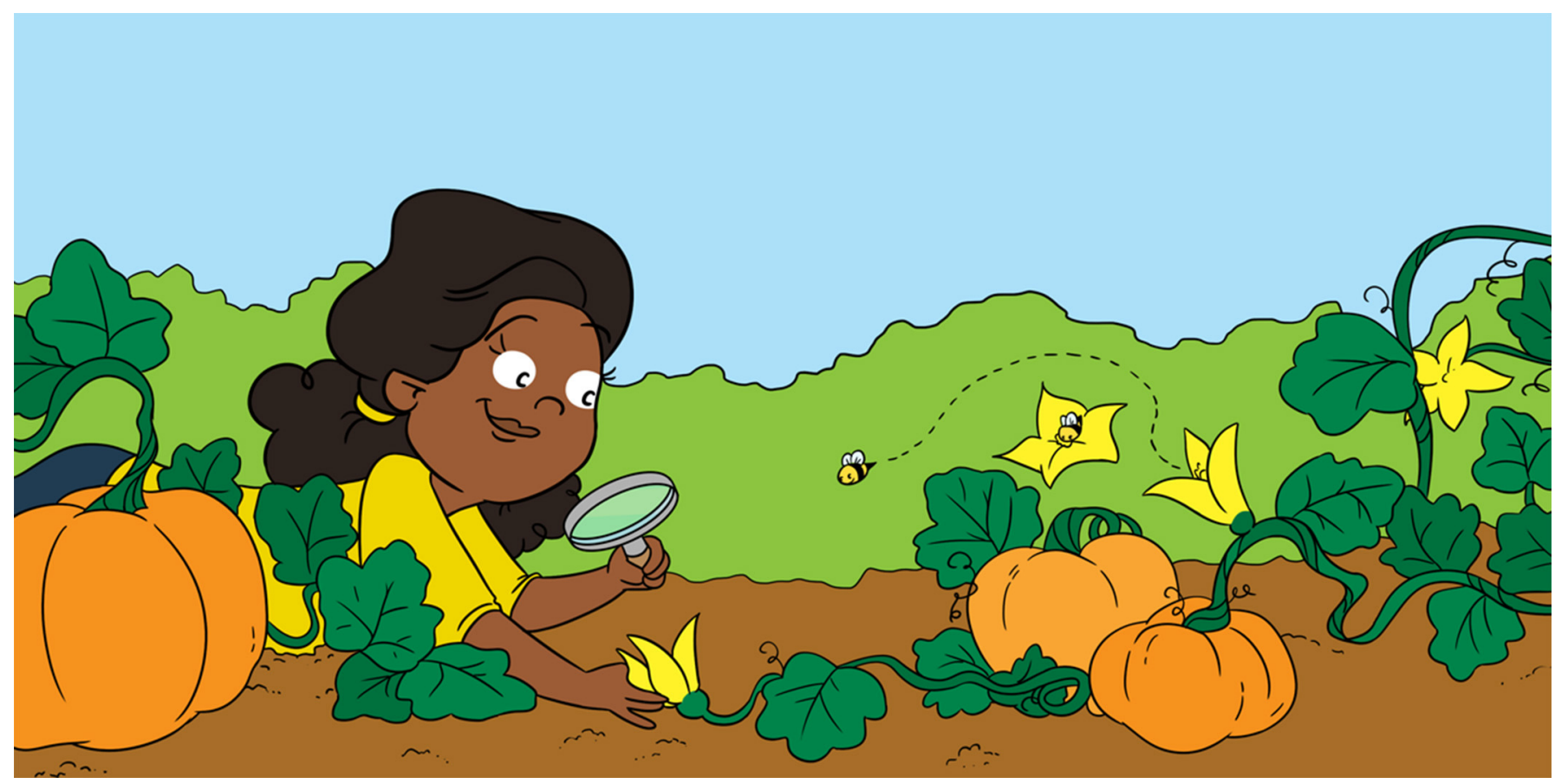

\title{
FLOWER POWER: A CLOSE LOOK AT PLANT REPRODUCTION
}

\author{
Katherine E. Dahlhausen ${ }^{1 *}$, David A. Coil ${ }^{1}$, Luca Comai ${ }^{1,2}$ and Isabelle M. Henry ${ }^{1,2}$ \\ ${ }^{1}$ Genome Center, University of California, Davis, Davis, CA, United States \\ ${ }^{2}$ Department of Plant Biology, University of California, Davis, Davis, CA, United States
}

YOUNG REVIEWERS:

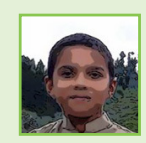

ABDUL

AGE: 13

MERCY

SCHOOL

AGES: $14-15$

\section{POLLEN}

Microscopic grains that grow on the male part of flowers at the end of anthers (see Figure 1) that can fertilize the female part of flowers (see "Ovule").
We all know that most of the food we eat comes from seeds, planted in fields or orchards, but have you ever thought about where the seeds themselves come from? Have you ever admired the inside of a beautiful flower? Believe it or not, these two questions are connected! Keep reading to learn about the different ways plant can reproduce and how scientists study plant reproduction. You will also get to learn about the advantages of different methods of plant reproduction and why the way that plants reproduce is important to us, as humans.

\section{LEARNING ABOUT PLANT REPRODUCTION IS IMPORTANT!}

Everybody knows that flowering plants usually grow from seeds, but have you ever wondered where the seeds come from? Seeds are made when pollen (from the male part of a flower) reaches the ovule (from the female part of a flower). It seems simple enough, but there are 
Figure 1

The anatomy of flowers that use different modes of plant reproduction. (A) A hermaphroditic selfer. The pollen can fertilize the ovules that are inside the same flower.

(B) Outcrossing dioecious plants, in which one plant has only female flowers and another has only male flowers. The pollen from the male plant needs to travel to the ovules inside the flower of the female plant in order to fertilize them.

\section{OVULE}

The female part of a flower that can be fertilized (see "pollen").

\section{SELFER}

A plant that fertilizes its own ovules with its own pollen, so it can make seeds on its own. Selfers include both monoecious and hermaphroditic plants.

HERMAPHRODITIC (HER.MAF.ROW DIT.ICK)

A plant that has both male and female reproductive organs that (often) are in the same flower.

\section{MONOECIOUS}

(MAH.NEE.SHUHS)

A plant that has both male and female reproductive organs that are in different flowers.

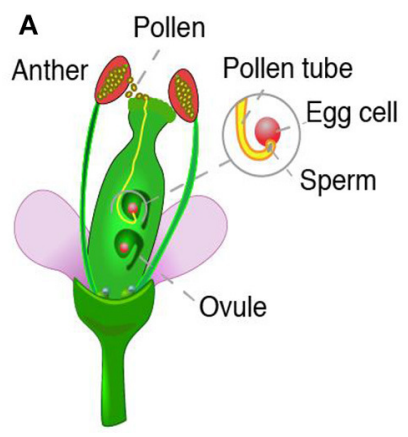

Selfer

(Hermaphrodite)

\section{B}

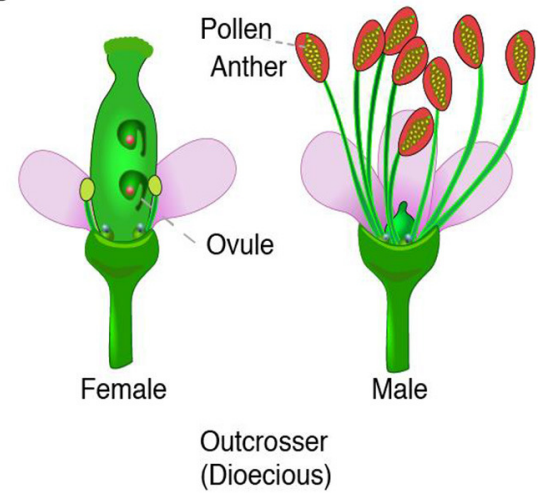

Figure 1

actually several different ways that plants can reproduce! In this article you will to learn about some of the methods of plant reproduction, as well as some of the advantages and disadvantages of these different modes of reproduction.

There are many reasons why it is important for scientists to study plant reproduction. For example, plants are very important for the foods you, your family, your friends, your teachers, and even your pets eat. We can eat plants directly, like fruits and vegetables. We need plants for our other foods too, like the grass that cows eat to give us milk, cheese, and yogurt. By learning about the plants that we need for food, scientists can figure out how we can grow more of these plants, how to grow them more efficiently, and how to use less of valuable resources such as land and water, in the cultivation of these foods. Other than food, can you think of more ways that we use plants?

\section{SELFERS AND OUTCROSSERS: HOW ARE THESE TWO TYPES OF PLANTS DIFFERENT?}

Self-fertilizing plants, known as selfers, make pollen that can fertilize their own ovules (Figure 1A). If a flower has both female and male parts, it is called hermaphroditic. Sometimes there are separate female and male flowers, but they are on the same plant. These plants are called monoecious (meaning "one house"). Monoecious plants are examples of selfers because they do not need two separate plants in order to reproduce. How many of the selfers pictured in Figure 2 do you know?

Cross-fertilizing plants, known as outcrossers, need two separate plants in order to reproduce. Sometimes, a flower can have both pollen and ovules, but they cannot fertilize each other; this is called self-incompatibility. For outcrossers to successfully reproduce, the pollen and ovules need to be from separate plants. In other cases, the two sexes are completely separate, with some plants making only male 
Figure 2

How many of these examples of plants with hermaphrodite flowers and separate male and female flowers do you know? Hermaphrodite selfers include tomatoes, eggplants, and green beans. Hermaphrodite outcrossers include walnuts, apples, and potatoes. Selfers with separate flowers (monoecious) include pumpkins, bananas, and corn. Outcrossers with separate flowers (dioecious) include holly, asparagus, and kiwi.

\section{OUTCROSSER}

A plant whose ovules are fertilized by the pollen of a different plant of the same species. Sometimes outcrossers have male and female reproductive organs on the same plant, but they still need to be fertilized by a separate plant.

\section{DIOECIOUS}

(DIE.EE.SHUHS)

A plant that has only all-male flowers or only all-female flowers.
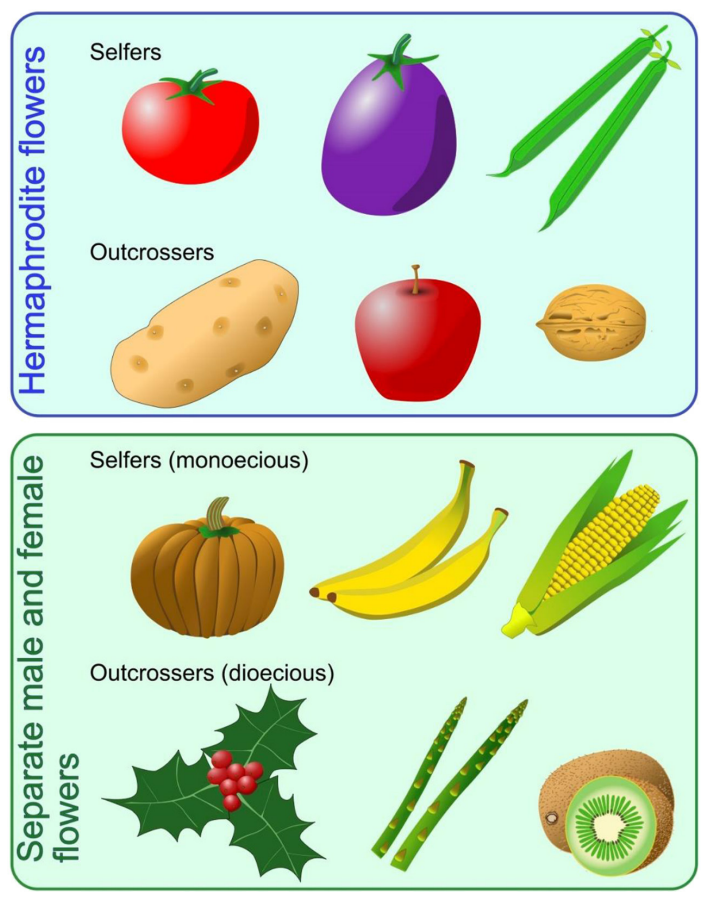

Figure 2

flowers and other plants making only female flowers. This is similar to how reproduction works in most animals. Scientists call these plants dioecious (meaning "two houses") (Figure 1B). The pollen from the male plants needs to travel to the ovules of the female plant in order to produce seeds. Only about 5\% of known plant species are dioecious, but that does not mean they are not common! [1]. How many of the outcrossers pictured in Figure 2 do you know?

\section{HOW DO SCIENTISTS STUDY DIOECIOUS PLANTS?}

There are still a lot of mysteries about how and why some types of outcrossers are dioecious. Scientists decided to look at the DNA from many different kinds of dioecious plants to try to understand what makes them male or female. There is a lot you can learn from DNA that may not be so obvious from just looking at or growing a plant. A DNA sequence is a lot like letters on a keyboard: the letters by themselves do not mean anything, but when they are put together they can form words. These "words" in the DNA are called genes and they give plants information, such as what shape their leaves will be, whether they make thorns or not, or if they will be male or female.

Scientists compared the genes from several dioecious plants to figure out which genes were important in determining whether a plant is male or female. They discovered that there are several ways a plant can determine gender. For example, there can be genes in the DNA that make plants male or genes that prevent them from becoming female [1]. 
Looking at plant DNA is not the only way scientists can learn about the differences between male and female plants. For example, they can study the shape differences between male flowers and female flowers. You can do this too!

\section{ADVANTAGES AND DISADVANTAGES OF REPRODUCTION METHODS}

Unlike humans, plants cannot move around. This means that plants need to use other strategies to move pollen to ovules to make seeds. For outcrossers, the male plants do not need to spend their energy making seeds, so they can spend more energy on making and dispersing high-quality pollen. Similarly, since female plants do not need to make pollen, they can spend more energy on making high-quality ovules. This means that they can pass on more resources to their offspring to improve their chances of survival. Furthermore, because dioecious plants need two different plants to reproduce, the offspring will have more variety in the genes they get from the parents. This is especially important if the environment changes, because the offspring with greater variety in their genes will be more likely to have genes that help them adapt to a new environment. On the other hand, selfers, whose offspring only have genes from their one parent, would have less variety in their genes and might have more trouble adapting to environmental changes. This is a pretty great advantage for outcrossers! You learned earlier that only $5 \%$ of plant species reproduce this way-that is not a lot. Can you think of any reasons why outcrossing might not be the best strategy for a plant to reproduce?

Scientists have a couple ideas why outcrossers may not be as common as selfers. First, since male and female outcrossers need similar environments and resources to survive, they would need to compete with each other if they are too close together. Thirty-one percent of dioecious plants avoid the issue of competition by relying on the wind to carry pollen to the female plants. This is much higher than the $6 \%$ of selfers that use wind pollination (Figure 3A) [1]. While the plants are no longer competing for resources when they use the wind for pollination, the males then need to make much more pollen in order to increase the chances that their pollen reaches the distant female ovules. You can think of this like shooting basketballs into a hoop (Figure 3B). Being a selfer is a lot like shooting basketballs from right under the basketball hoop. Being a dioecious plant is like shooting basketballs at the hoop from half court: you need a lot more basketballs to increase your chances of making it in the hoop.

The second reason outcrossers might not be as common as selfers is that neither the males nor females can make offspring without the other. If all of the males or all of the females were to die, then the plant species would go extinct. Selfers do not need to worry about 
Figure 3

Many dioecious plants use the wind to help with pollination. (A) Only $6 \%$ of selfers but $31 \%$ of dioecious plants use wind for pollination. (B) Wind pollination uses much more pollen! Just like shooting basketballs, the further away you are from the hoop (female ovule), the more "shots" (pollen grains) you will need to take to increase your chances of making it in the "hoop."

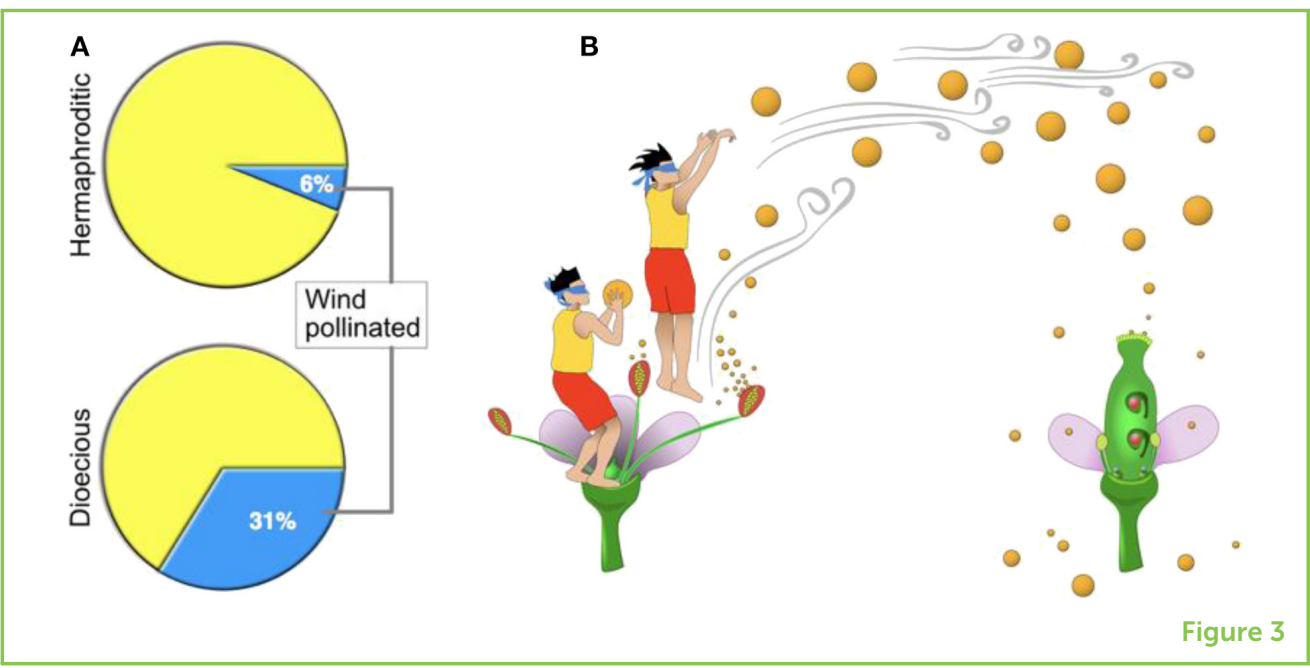

this issue because they are not dependent on other plants to make more seeds.

\section{HOW DOES THIS INFORMATION HELP FARMERS?}

Farmers are very important to us because they grow the food that we need to survive. Scientists can share what they learn about plants with farmers so they can grow more food, or do so more efficiently. Let us say you are a farmer and you want to grow kiwi vines, which you now know are dioecious. As a farmer, you need to grow male kiwi trees, which do not make kiwifruit but are needed to make pollen for the female kiwi trees. You can ask scientists what is the fewest number of male kiwi vines that would be needed to pollinate the female vines so you do not waste extra resources like land and water to grow unnecessary male vines. Furthermore, as a kiwi farmer, you know that you need to grow your vines for multiple years before they start producing fruit. When a kiwi vine is young, it is hard to tell if it male or female. You can ask scientists to look at the DNA of your young kiwi vines to help you figure out which ones are male. You can use this information to make sure the male plants are spread out on your farm, and that there are not too many male vines.

\section{CONCLUSION}

Now that you have learned more about how plant reproduction works, you may look at plants in a different way. Next time you see a flower, maybe you will want to take a closer look. Can you tell if it has male parts or female parts or both? Next time you see a plant that we mentioned in this article, maybe you will let your family and friends know about it. "Hey, did you know that the kiwi on my plate is from a dioecious plant?!" 


\section{ORIGINAL SOURCE ARTICLE}

Henry, I. M., Akagi, A., Tao, R., and Comai, L. 2018. One hundred ways to invent the sexes: theoretical and observed paths to dioecy in plants. Annu. Rev. Plant Biol. 69:553-75. doi: 10.1146/annurev-arplant-042 817-040615

\section{REFERENCES}

1. Henry, I. M., Akagi, A., Tao, R., and Comai, L. 2018. One hundred ways to invent the sexes: theoretical and observed paths to dioecy in plants. Annu. Rev. Plant Biol. 69:553-75. doi: 10.1146/annurev-arplant-042817-040615

SUBMITTED: 11 July 2019; ACCEPTED: 24 January 2020;

PUBLISHED ONLINE: 21 February 2020.

EDITED BY: Johnathan J. Dalzell, Queen's University Belfast, United Kingdom

CITATION: Dahlhausen KE, Coil DA, Comai L and Henry IM (2020) Flower Power: A Close Look at Plant Reproduction. Front. Young Minds 8:8. doi: 10.3389/frym.2020. 00008

CONFLICT OF INTEREST: The authors declare that the research was conducted in the absence of any commercial or financial relationships that could be construed as a potential conflict of interest.

COPYRIGHT @ 2020 Dahlhausen, Coil, Comai and Henry. This is an open-access article distributed under the terms of the Creative Commons Attribution License (CC BY). The use, distribution or reproduction in other forums is permitted, provided the original author(s) and the copyright owner(s) are credited and that the original publication in this journal is cited, in accordance with accepted academic practice. No use, distribution or reproduction is permitted which does not comply with these terms.

\section{YOUNG REVIEWERS}

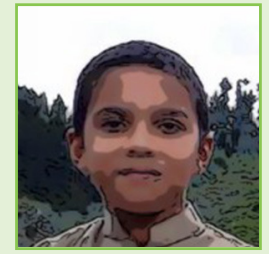

\section{ABDUL, AGE: 13}

Abdul is very much interested in biodiversity with special attention to extinct or endangered species. He likes life in oceans, mountains, and wishes to find it in space if any. He has wonderful love for drawing various scenaries of natures.

\section{MERCY SCHOOL, AGES: 14-15}

We are an inventor class! We love to build and create in order to find solutions to real world problems. Our students come from all over the area to attend school. 

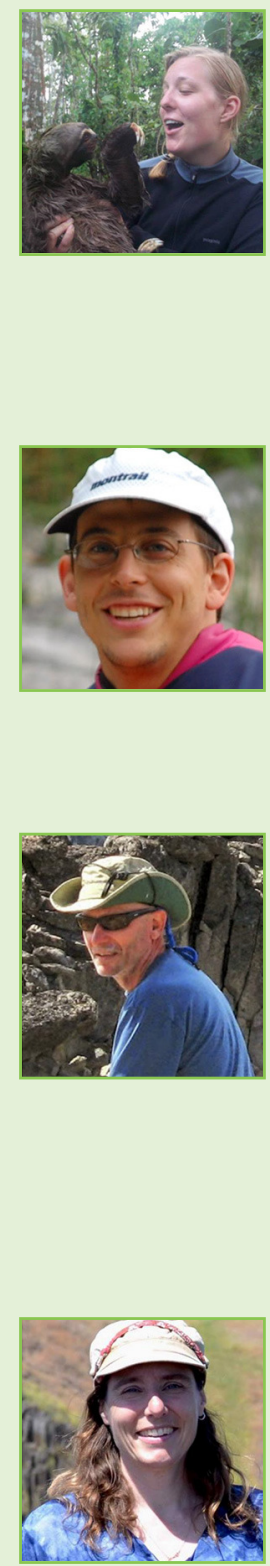

\section{AUTHORS}

\section{KATHERINE E. DAHLHAUSEN}

Katherine graduated from Lewis and Clark College in Portland, Oregon with a double major in Physics and Biology. She then moved to California to start her Ph.D. at the University of California, Davis, working in the laboratory of her super cool boss, Dr. Jonathan Eisen. Katherine has a wide range of research and education interests, but her primary research is understanding how medicine changes microbial communities in koalas. Her favorite things to do are hang out with kids and explore nature! *katdah@ucdavis.edu

\section{DAVID A. COIL}

David studies microbes at the University of California, Davis in the laboratory of Dr. Jonathan Eisen. He got his Ph.D. in 2005, studying how viruses enter cells. Since then he has worked on bacterial villains and a wide range of interesting microbes from cool places, including cat butts, hummingbirds, seagrasses, and the space station. David is particularly interested in education and communicating science to the public.

\section{LUCA COMAI}

Luca is a professor at the University of California, Davis. There, he leads a research group that studies how plant DNA is organized. He grew up in Italy, where he received his bachelor's degree in Agriculture from the University of Bologna. He moved to the US to attend graduate school and obtained his Ph.D. in 1980, studying plant diseases. Since then, he has worked on a wide variety of projects and almost as many different plant species, always interested in understanding how they function, and particularly what happens when their chromosomes change. Amongst other hobbies, he enjoys drawing, as exemplified by the figures included in this article.

\section{ISABELLE M. HENRY}

Isabelle is originally from Belgium but she received her Ph.D. from the University of Washington in Seattle, studying how plants respond to changes in chromosome numbers. She has been a Project Scientist at the UC Davis Genome Center and a member of the Plant Biology department since 2011. She is interested in understanding the importance of chromosome number on plant function in a wide variety of crops and plant species. For example, she studies plant sex chromosomes in persimmon, or the effect of adding or removing chromosome pieces on wood formation in poplar trees. 